\title{
The Combination of Entomopathogenic Fungus of Beauveria bassiana (Balls) Vuill. with the Insect Growth Regulator (IGR) of Lufenuron Against Reproductive of Bactrocera carambolae Fruit Flies (Diptera: Tephritidae)
}

\author{
Adrianto Marthinus $\mathrm{Ndii}^{{ }^{*}}$, Bambang Tri Rahardjo ${ }^{2}$, Toto Himawan ${ }^{3}$ \\ ${ }^{1}$ Master Program of Plant Sciences, Faculty of Agriculture, University of Brawijaya, Malang, Indonesia \\ ${ }^{2}$ Department of Plant Sciences, Faculty of Agriculture, University of Brawijaya, Malang, Indonesia \\ ${ }^{3}$ Laboraty of Pest and Laboratory of Pesticide Toxicology, Faculty of Agriculture, University of Brawijaya, Malang, \\ Indonesia
}

Abstract

The study aimed to determine the reproductive ability of fruit flies $B$. carambolae treated with $B$. bassiana and Lufenuron. This study is conducted at the Laboratory of Pest. Department of Plant Pests and Diseases, Faculty of Agriculture, University of Brawijaya, Malang. This study used a completely randomized design with nine treatment and three replications. The study was trying to evaluate the effect of $B$. bassiana and Lufenuron on the reproduction capacity of $B$. carambolae. Results showed that adults of $B$. carambolae to applied combination of $B$. bassiana and Lufenuron immediately after coming out of the pupae until day eighth have the average number of eggs laid is $7.69 \%$, a decrease of fecundity $92.40 \%$, egg fertility by $61.38 \%$ and $95.24 \%$ decrease of reproduction. Adults of $B$. carambolae applied of $B$. bassiana and Lufenuron on day eighth until day sixteenth (for 8 days), show a decrease in the number of eggs laid by $13.63 \%$, the decrease of fecundity $88.50 \%$, egg fertility by $50.16 \%$ and decrease of reproduction by $93.12 \%$.

Keywords: Bactrocera carambolae, Beauveria bassiana, Lufenuron.

\section{INTRODUCTION}

The fruit fly is a pest so much affecting the horticultural crops. Under condition where the fruit fly populations are high, the intensity of the attack can reach $100 \%$ [1]. One type of fruit flies that need attention is Bactrocera carambolae (Diptera: Tephritidae). Fruit attacked by B. carambolae looks intact from the outside, but the inside of the fruit is actually destroyed as it has been eaten by the larvae of $B$. carambolae [2].

Bactrocera carambolae larvae control using pathogenic microorganisms is more effective because it is environmentally friendly and does not cause resistance on the species. One of pathogenic microorganisms that can be used for larval control of $B$. carambolae is the fungus Beauveria bassiana (Bals) Vuill. The pathogenicity of this fungus is not consistent when applied in the field, due to the influence of environmental conditions that do not support especially temperature, humidity, and the intensity of sunlight. The pathogenicity of the fungus $B$. bassiana can be improved by formulation of

\footnotetext{
* Correspondence author: Adrianto Marthinus Ndi

Email : ndiiryan@gmail.com

Address : Master Program of Plant Sciences, University of Brawijaya, Jl. Veteran Malang, 65145
}

isolates with the addition of Insect Growth Regulator (IGR).

IGR is a product or material that interferes with or inhibits the life cycle of pests, such that pests cannot reach imago, and unable to reproduce [3]. One of the insecticide active ingredients included in the IGR is Lufenuron. Lufenuron works by inhibiting the synthesis of chitin in the process of ecdysis. In addition to inhibiting the synthesis of chitin, Lufenuron also interferes with the reproductive system of the insects pest target [4]. The combination of $B$. bassiana fungus with the addition of IGR is expected to be a new approach for controlling $B$. carambolae effectively, environmentally friendly. Which in turn does not cause resistance and does not cause the death of natural enemies of both predators and parasitoids as well as to improve the quality of fruits and vegetables [5]. Increased pathogenicity of entomopathogenic fungi by the addition of insecticides can fix isolate and improve the performance of these isolates [6].

According to above previous research, there is a need for research on the combination of entomopathogenic fungus Beuaveria bassiana (Balls) Vuill with the Insect Growth Regulator (IGR) of Lufenuron against reproductive of Bactocera carambolae fruit flies (Diptera: Teprhitidae). This study aims to determine the 
reproductive ability of fruit flies $B$. carambolae treated with $B$. bassiana and Lufenuron.

\section{MATERIALS AND METHODS Study Object}

Male and female imago were treated in separate cages. Each cage consisted of 10 imago. Imago separation was done because there was a difference in treatment between male and female imago. Male and female imago of $B$. carambolae respectively were treated with $B$. bassiana + Lufenuron with $1.5 \mathrm{~mL}^{-L^{-1}}$ concentration. Beauveria bassiana was added with Lufenuron for imago of $B$. carambolae for applications. Applications to B. carambolae was done by using a saturated sponge and placed on top of the treatment cage. Differences in the treatment of adult males and females were conducted to determine the effect of $B$. bassiana + Lufenuron to the death of $B$. carambolae. Each treatment in the imago is presented in Table 2.

Table 1. Treatment of $B$. bassiana and Lufenuron on the Imago of $B$. Carambolae

\begin{tabular}{|c|c|}
\hline Treatment & Application (Day) \\
\hline$\hat{\sigma}$ BL1 $><+$ Normal $\left(P_{1}\right)$ & $1-8$ \\
\hline o BL1 $><$ Normal $\left(\mathrm{P}_{2}\right)$ & $1-8$ \\
\hline$\hat{\mathrm{B} L 1}><+\operatorname{BL} 1\left(\mathrm{P}_{3}\right)$ & $1-8$ \\
\hline BL8 $><+$ Normal $\left(P_{4}\right)$ & $8-16$ \\
\hline q BL8 $><\lesssim$ Normal $\left(\mathrm{P}_{5}\right)$ & $8-16$ \\
\hline$\hat{o} \mathrm{BL} 8><+\mathrm{BL} 8\left(\mathrm{P}_{6}\right)$ & $8-16$ \\
\hline Control $\left(P_{7}\right)$ & 0 \\
\hline Control $\left(\mathrm{P}_{8}\right)$ & $1-8$ \\
\hline Control $\left(P_{9}\right)$ & $8-16$ \\
\hline
\end{tabular}

Description :

$\mathrm{BL}$ : Beauveria bassiana and Lufenuron

BL1 : Application the first day until the eighth day

BL8 : Application eight day until the sixteenth day

ô : Male Imago

: Female imago

\section{Data Collection and Analysis}

Date of the eggs number and formed imago were obtained by direct observation. The calculation was conducted on the eggs number placed by the $B$. carambolae imago and then counts the number of eggs capable of being larva, pupa, up until the imago. Data were analyzed using analysis of variance (ANOVA), if there is a significant difference then continued with Duncan's Multiple Range Test at 5\% level.

\section{RESULT AND DISCUSSION}

\section{Fecundity of Fruit Flies B. carambolae}

Fecundity of fruit flies that were applied the combination $B$. bassiana and Lufenuron can be seen in the Table 2. The lowest mean number of eggs was for $P_{3}$ (male and female were alike given $B$. bassiana combined with Lufenuron 1.5 $\mathrm{mL} . \mathrm{L}^{-1}$ in the medium for pupation for effective pupation in suppressing the formation of pupae. The lowest number of eggs was for treatment $P_{6}$ (male and female were alike given $B$. bassiana combined with Lufenuron), which was 131.67. All treatments provided real difference to the average number of eggs laid by imago $B$. carambolae on controls. The decline in fecundity of $B$. carambolae imago can be known by subtracting the average number of eggs in the control group with the one in the experiment group divided by the number of eggs in control group and then multiplied by one hundred.

In Table 2, the highest decrease in fecundity of $B$. carambolae imago for those mated on day eighth after the treatment was in $P_{3}$ (male and female were alike given $B$. bassiana combined with Lufenuron) which was $92.40 \%$. While the highest fecundity for those mated on day sixteenth after the treatment was in $\mathrm{P}_{6}$ (male and female were alike given $B$. bassiana combined with Lufenuron) which was $88.50 \%$. This shows that the male and female imago of $B$. carambolae treated with $B$. bassiana and lufenuron was effective in reducing fecundity of fruit fly $B$. carambolae. The decline in fecundity was also due to premature death of imago of $B$. carambolae given $B$. bassiana and Lufenuron.

Table 2. The Average Fecundity and the Decrease in Fecundity of Fruit Fly $B$. carambolae Treated with B. bassiana and Lufenuron on Different Ages

\begin{tabular}{|c|c|c|}
\hline Treatment & $\begin{array}{c}\text { Average } \\
\text { Number of } \\
\text { Eggs (Pcs) }\end{array}$ & $\begin{array}{l}\text { Decrease in } \\
\text { Fecundity (\%) }\end{array}$ \\
\hline$\hat{o} \mathrm{BL} 1><\mathrm{O}$ BL1 $\left(\mathrm{P}_{3}\right)$ & $290.00 \mathrm{abcd}$ & 92.40 \\
\hline đo BL $8><$ Normal $\left(\mathrm{P}_{4}\right)$ & $213.00 \mathrm{abc}$ & 81.40 \\
\hline 우 BL8 $><\overbrace{}^{\wedge}$ Normal $\left(P_{5}\right)$ & $154.67 \mathrm{ab}$ & 86.50 \\
\hline$\hat{0} \mathrm{BL} 8><+$ BL8 $\left(\mathrm{P}_{6}\right)$ & $131.67 \mathrm{a}$ & 88.50 \\
\hline Control $\left(P_{7}\right)$ & $6651.33 \mathrm{i}$ & 0.00 \\
\hline Control $\left(P_{8}\right)$ & $3813.33 \mathrm{~h}$ & 0.00 \\
\hline Control $\left(P_{9}\right)$ & $1145.33 \mathrm{fg}$ & 0.00 \\
\hline
\end{tabular}

Description :

BL : Beauveria bassiana and Lufenuron

BL1 : Application the first day until the eighth day

BL8 : Application eight day until the sixteenth day

ô : Male Imago

ㅇ : Female imago

Different notation indicates a significant difference $(\mathrm{P}<0.05)$.

Beauveria bassiana applied to the imago of Tetranychus urticae reduces the number of eggs placed by the imago of $T$. urticae up to $98 \%$ [10]. Combination of fungus of $B$. bassiana and 
Lufenuron $1.5 \mathrm{~mL} . \mathrm{L}^{-1}$ results in the average number of eggs by $12.42 \%$ compared with the untreated imago. This means that the decline in the number of eggs is $87.58 \%$ [5]. Application of B. bassiana with concentration of spores at $2.0 \mathrm{x}$ $10^{7}$ is able to reduce female fecundity of green leaf hoppers up to $58 \%$ [7].

Observation on present studies shows that the infected imago of $B$. carambolae mostly die prematurely. This is because $B$. bassiana enters the insect host's body through the skin, gastrointestinal tract, spiracles, and other openings (Fig. 1). In addition, inoculum of fungi that attach to the body of the insect host can germinate and grow to form a tubular sprouts, then penetrate through the cuticle of the insect body. The penetration is done mechanically or chemically by enzymes or toxins [8].

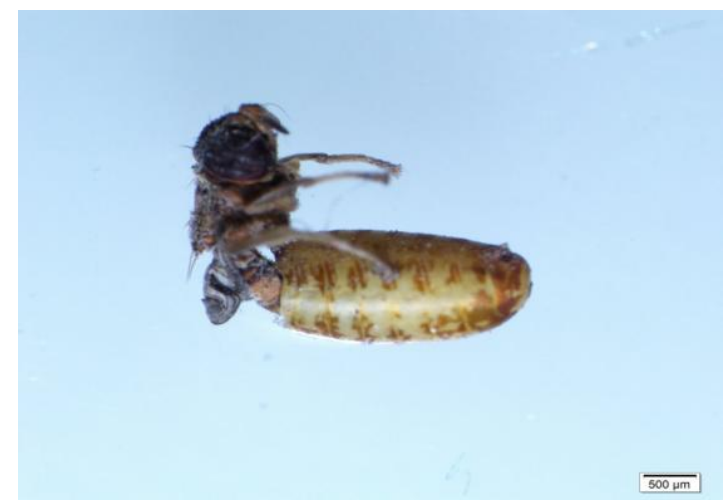

Figure 1. Imago of B. caramboale that Infected with $B$. bassiana and Lufenuron Combination

\section{Fertility of Fruit Flies B. carambolae}

The results show that there were differences between the mean on fertility of treated and untreated eggs of B. carambolae fruit fly. This indicates that $B$. bassiana combined with Lufenuron affected fertility of eggs. Table 3 shows that the lowest percentage of egg hatching on imago of $B$. carambolae mated on day eighth after being treated was in $\mathrm{P}_{3}$ (female treatment vs male treatment) reaching $55.39 \%$ when compared to the imago of $B$. carambolae mated at same age, which was $99.30 \%$. While in the imago of $B$. carambolae mated on day sixteenth after the treatment, the lowest average of egg hatching was in $\mathrm{P}_{6}$ (male and female treated) which reached $50.16 \%$ when compared to the control group of imago of $B$. carambolae which reached $99.27 \%$. Table 3 also shows that the highest decrease in reproduction was in $\mathrm{P}_{3}$ (male and female equally treated) which reached 95.24\%. However, almost all treatments could affect the reproductive decline when compared to the imago of $B$. carambolae in control.

Beauveria bassiana fungus will further produce beauverin toxins making damage to the insect tissue. Within days, the insects will die (Fig. 2 ). The mycelium of the fungus will come out of the host's body, grow over the host's body, and produce conidium. Insects attacked by Beauveria bassiana will die with a hardened body like a mummy and covered by threads of white hyphae. Lufenuron combined with $B$. bassiana will release toxins that cause blood clotting and cessation of blood circulation to the insect that the insect will die [5].

Table 3. The Average Fertility and the Decrease in Reproductive Function of Fruit Fly $B$. carambolae Treated with $B$. bassiana and Lufenuron on Different Ages

\begin{tabular}{|c|c|c|}
\hline Treatment & $\begin{array}{l}\text { Average } \\
\text { Number of } \\
\text { Egg } \\
\text { Hatching } \\
\text { (Pcs) }\end{array}$ & $\begin{array}{l}\text { Decrease in } \\
\text { Reproductive } \\
\text { Function (\%) }\end{array}$ \\
\hline$\hat{\delta}$ BL1 $><$ Normal $\left(P_{1}\right)$ & 451.33 ef & 85.26 \\
\hline o BL1 $><$ Normal $\left(P_{2}\right)$ & 217.67 cde & 92.89 \\
\hline o $\mathrm{BL} 1><+$ BL1 $\left(\mathrm{P}_{3}\right)$ & $145.67 \mathrm{bc}$ & 95.24 \\
\hline đ BL8 $><$ Normal $\left(\mathrm{P}_{4}\right)$ & $98.33 \mathrm{ab}$ & 87.07 \\
\hline o BL8 $><\overbrace{}^{\lambda}$ Normal $\left(P_{5}\right)$ & $67 a$ & 91.19 \\
\hline o $\mathrm{BL} 8><+$ BL8 $\left(\mathrm{P}_{6}\right)$ & $52.33 \mathrm{a}$ & 93.12 \\
\hline Control $\left(P_{7}\right)$ & $5341.67 \mathrm{i}$ & 0 \\
\hline Control $\left(P_{8}\right)$ & $3062.33 \mathrm{~h}$ & 0 \\
\hline Control $\left(P_{9}\right)$ & $760.33 \mathrm{~g}$ & 0 \\
\hline
\end{tabular}

\section{Description :}

BL : Beauveria bassiana and Lufenuron

BL1 : Application the first day until the eighth day

BL8 : Application eight day until the sixteenth day

o : Male Imago

q : Female imago

Different notation indicates a significant difference $(P<0.05)$.

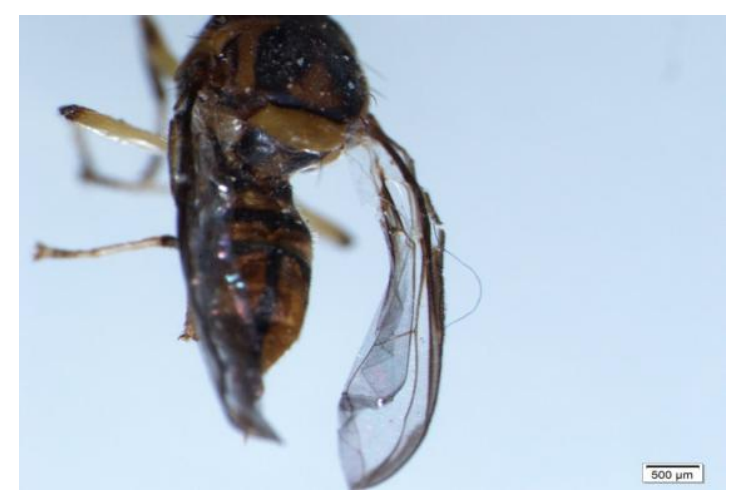

Figure 2. Imago $B$. bassiana dead Stricken by the Combination of $B$. bassiana and Lufenuron

Beauveria bassiana can produce mycotoxins in the form of beauvericin toxins that cause 
damage to the parts of the egg and the embryo causing disruption in the function of the haemolymph and nucleus of the insects. In addition, Beauveria bassiana can also generate secondary bassianolid metabolites like beuverolit, isorolit, and oxalic acid that its mechanism leads to the increase in $\mathrm{pH}$ of haemolymph, clumping of haemolymph, and cessation in the circulation of haemocytes as well as tissue or mechanic organ damage such as the gastrointestinal tract, muscles, nervous system, respiratory system and these disorders cause death [9].

\section{CONCLUSION}

Combination treatment of $B$. bassiana and Lufenuron influence the fecundity and fertility of B. carambolae imago, i.e. $92.40 \%$ decline in fecundity and fertility decline $93.12 \%$. The combination of fungus $B$. bassiana and IGR Lufenuron that applied on fruit fly imago $B$. carambolae can inhibit the reproduction of fruit flies experiments in the laboratory. However, it need further research on the field application thus it can be used for pest control in the agriculture practices.

\section{REFERENCES}

[1] Yulistiono, H. 2009. Keberadaan spesies lalat buah (Bactrocera spp) pada lahan kering di Kabupaten Lombok Barat. Master Thesis. Department of Plant Science, University of Mataram: Mataram.

[2] Kuswadi, A.N., Darmawi, M. Indarwatmi, 1997. Biologi lalat buah Bactrocera carambolae dalam biakan di laboratorium dengan makanan buatan. Proceeding of National Seminar of Biology XV. PEI and University of Lampung, Bandar Lampung. 1510-1514.

[3] Shalby, E.M.S. 2006. Comparative haematological and hepatorenal toxicity of IGR, Lufenuron and Profenofos insecticide on albino rats. Department of Pests and Plant Protection, National Research Centre Dokki: Cairo, Egypt.

[4] Hoffman, K.H., M.W. Lorenz. 1998. Recent advances in hormones in insect pest control. Phytoparasitica. Available at: http://www.beyondpesticides.org/infoservic es/pesticidefactsheets/toxic/insectgrowthre gulators.htm.

[5] Hadi, M.S. 2013. Efektivitas jamur entomopatogen Beauveria bassiana (bals) vuill. dengan penambahan Insect Growth Regulator (IGR) Lufenuron untuk pengendalian hama lalat buah Bactrocera carambolae (drew dan hancock) (Diptera: Tephritidae). Master Thesis. Department of Plant Science, University of Brawijaya: Malang.

[6] Asi, M.R., M.H. Bashir, M. Afzal, M. Ashfaq, T.S. Sahi. 2010. Compatibility of entomophatogenic fungi Metarhizium anisopliae and Paecilomyces fumosoroseus with selective insecticides. Departement of Plant Diseases, University of Agriculture, Faisalabad: Pakistan.

[7] Widiarta, I.N., D. Kusdiaman. 2007. Penggunaan jamur entomopatogen Metharizum anisoplae dan Beauveria bassiana untuk mengendalikan populasi Wereng Hijau. Research Center of Paddy (Balai Besar Penelitian Tanaman Padi): Subang, West Java. 4654.

[8] Deciyanto, S., I.G.A.A. Indrayani. 2008. Jamur entomopatogen Beauveria bassiana: potensi dan prospeknya dalm pengendalian hama Tungau. Research Center of Tobacco and FIber Plants (Balai Penelitian Tanaman Tembakau dan Serat): Malang.

[9] Rahmayuni, A., Fatahudin.2013. Pengaruh cendawan Beauveria bassiana vuillemin terhadap mortalitas dan parasitisasi telur Helicoverpa armigera hubner pada tanaman jagung. Thesis. Faculty of Agriculture. Hassanudin University: Makasar. 